\title{
PENGEMBANGAN PENINGKATAN KUALITAS PEMBUATAN LAPORAN KEUANGAN SEDERHANA HOME INDUSTRY DI LINGKUNGAN KECAMATAN MATESIH KARANGANYAR
}

\author{
${ }^{1}$ Yosephine Angelina Yulia, ${ }^{2}$ Andri Octaviani, ${ }^{3}$ Hanif Safika \\ STIE AUB Surakarta \\ andry.oktavia@stie-aub.ac.id
}

\section{Abstrak: \\ Pengembangan Peningkatan Kualitas Pembuatan Laporan Keuangan Sederhana Home Industry di Lingkungan Kecamatan Matesih Karanganyar.}

Kabupaten Karanganyar merupakan tempat UMKM yang berkembang. Persebaran skala usaha UMKM di Kabupaten Karanganyar bervariasi dengan rata-rata usia usaha selama 11 tahun. Terdapat sekitar 37 persen UMKM berskala mikro, 32 persen berskala kecil dan 31 persen berskala menengah. Jika dilihat dari aspek pengembangan usaha, secara umum hanya sekitar 17 persen UMKM yang tidak memiliki hambatan berusaha. Beberapa jenis hambatan berusaha tersebut antara lain yaitu: hambatan persaingan (persaingan klaster, persaingan domestik dan persaingan luar negeri), penyelundupan, kebjakan ekonomi, kebijakan harga, penguasaan teknologi, permodalan dan manajerial. Pada kenyataanya praktek kegiatan UKM selalu berjalan tanpa mengandalkan informasi keuangan yang disusun secara tertib dan teratur. Banyak UMKM yang dapat berjalan normal tanpa dukungan informasi keuangan yang memadai. Pelatihan pembuatan laporan keuangan sederhana sangat penting sekali untuk dikuasai terutama sekali tentang cara perhitungannya. Apalagi jika UMKM membutuhkan modal dari Bank, jika UMKM sudah mempunyai laporan keuangan sederhana maka pihak Bank akan lebih mempermudah proses peminjaman dana untuk modal. Selain itu ada banyak kasus usaha kecil yang salah dalam membuat laporan keuangan secara sederhana. Karena seyogyanya dalam membangun usaha, penjual dituntut untuk mampu menghitung dan membuat laporan keuangan untuk usahanya sendiri guna mengetahui secara persis pendapatan yang diterima dan biaya yang dikeluarkan.

Kata kunci: kewirausahaan, UMKM, laporan keuangan sederhana

\section{PENDAHULUAN}

Kabupaten Karanganyar merupakan tempat

UMKM yang berkembang. Persebaran skala usaha UMKM di Kabupaten Karanganyar bervariasi dengan rata-rata usia usaha selama 11 tahun. Terdapat sekitar 37 persen UMKM berskala mikro, 32 persen berskala kecil dan 31 persen berskala menengah. Jika dilihat dari perspektif sektor usahanya; sebagian besar UMKM di Kabupaten Karanganyar yang bergerak di Sektor Industri Pengolahan. Terdapat sekitar 44 persen UMKM bergerak di sektor Industri Pengolahan, kemudian diikuti oleh Sektor Pertanian sebesar 29 persen; Sektor Jasa sebesar 12 persen; Sektor Perdagangan sebesar 11 persen; Sektor Pengangkutan sebesar 2 persen; serta Sektor Pertambangan dan Kontruksi masing-masing sebesar 1 persen. Di sisi lain jika dilihat dari aspek sebaran cakupan pemasaran, sebagian besar UMKM di Kabupaten Sukoharjo berorientasi lokal. Terdapat sekitar 43 persen UMKM di Kabupaten Sukoharjo memiliki pasar lokal, sementara 23 persen memiliki pasar regional, 29 persen pasar nasional dan hanya sekitar 4 persen memiliki pasar 
internasional atau berorientasi ekspor.

Jika dilihat dari aspek pengembangan usaha, secara umum hanya sekitar 17 persen UMKM yang tidak memiliki hambatan berusaha. Beberapa jenis hambatan berusaha tersebut antara lain yaitu: hambatan persaingan (persaingan klaster, persaingan domestik dan persaingan luar negeri), penyelundupan, kebjakan ekonomi, kebijakan harga, penguasaan teknologi, permodalan dan manajerial. Sementara itu, komoditi UMKM di Kabupaten Karanganyar memiliki potensi yang besar untuk dibiayai oleh lembaga keuangan dan perbankan. Hal tersebut ditunjukkan oleh fakta statistik yaitu sekitar 61 persen UMKM di Kabupaten Karanganyar menjalin kemitraan dengan perbankan sebagai salah satu alterntif sumber pembiayaan ketika melakukan ekspansi usaha. Meskipun demikian kualitas dan kuantitas pembinaan UMKM di Kabupaten Karanganyar masih rendah. Hal tersebut ditunjukkan oleh proporsi UMKM yang mendapatkan pembinaan yang hanya mencapai 29 persen. Akan tetapi, jika dilihat dari prospek pengembangan produk, sebagaian besar (sekitar 86,5 persen) produk UMKM di Kabupaten Karanganyar berada dalam siklus berkembang (41 persen) dan matang (45,5 persen). Siklus produk berkembang dan matang menunjukkan bahwa potensi tumbuh untuk produk UMKM di Kabupaten Karanganyar sangat baik.

Pada kenyataanya praktek kegiatan UKM selalu berjalan tanpa mengandalkan informasi keuangan yang disusun secara tertib dan teratur. Banyak UMKM yang dapat berjalan normal tanpa dukungan informasi keuangan yang memadai. Banyak yang beranggapn bila kegiatan penyusunan laporan keuangan, masih dianggap mewah dan belum sebanding dengan kegunaannya, dampaknya pelaku UKM tidak akan mengetahui secara persis berapa pendapatan (kas) yang diterimanya, berapa biaya operasi yang harus dikeluarkannya dan berapakah yang seharusnya masih tersisa.

Data UKM pada tahun 2018 yang ada di Kecamatan Matesih Kabupaten Karanganyar sebanyak 607 UKM. Hal ini menandakan banyaknya potensi UKM di Kecamatan Matesih untuk berkembang jika ditangani secara tepat baik dari sisi pemasaran, kualitas produk maupun pengelolaan keuangannya. Pelatihan pembuatan laporan keuangan sederhana sangat penting sekali untuk dikuasai terutama sekali tentang cara perhitungannya. Apalagi jika UMKM membutuhkan modal dari Bank, jika UMKM sudah mempunyai laporan keuangan sederhana maka pihak Bank akan lebih mempermudah proses peminjaman dana untuk modal. Selain itu ada banyak kasus usaha kecil yang salah dalam membuat laporan keuangan secara sederhana. Karena seyogyanya dalam membangun usaha, penjual dituntut untuk mampu menghitung dan membuat laporan keuangan untuk usahanya sendiri guna mengetahui secara persis pendapatan yang diterima dan biaya yang dikeluarkan.

\section{METODE}

Metode pengabdian kepada masyarakat
ini berupa Pelatihan dan Pendampingan
mengenai pentingnya pembuatan laporan keuangan
sederhana bagi masyarakat UMKM Kecamatan
Matesih Kabupaten Karanganyar dengan tujuan
memberikan edukasi pentingnya proses pembukuan
sederhana dalam menjalankan usaha.
Sasaran dari kegiatan pengabdian
masyarakat ini adalah Ibu-ibu PKK Kecamatan


Matesih Kabupaten Karanganyar yang mempunyai usaha menengah dan kecil. Program pengabdian kepada masyarakat ini dilaksanakan berkaitan dengan program Kuliah Kerja Nyata STIE AUB Surakarta yang diselenggarakan di Kabupaten Karanganyar.

\section{HASIL DAN PEMBAHASAN}

Kegiatan pelatihan pembuatan laporan keuangan sederhana dilaksanakan selama 5 bulan. Pelaksanaan pelatihan tentang pembuatan laporan keuangan sederhana dilaksanakan setelah kegiatan rutinitas harian masyarakat selesai. Adapun lokasi pelaksanaan pelatihan bertempat di Balai Desa Kecamatan Matesih Kabupaten Karanganyar. Peserta pelatihan terdiri atas Ibu-ibu PKK yang mempunyai usaha, perangkat dusun, dan masyarakat pelaku UMKM setempat. Peserta pelatihan yang hadir dalam kegiatan pengabdian kepada masyarakat adalah 81 orang.

Materi yang disampaikan adalah tentang penjurnalan dan laporan keuangan sederhana berupa laporan laba rugi. Narasumber memberikan contoh dan tahapan dalam membuat pembukuan sederhana. Berikut ini disajikan tahapan pelaksanaan kegiatan :

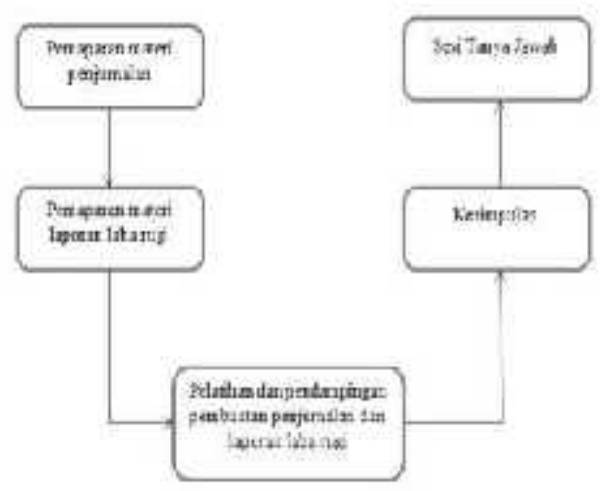

$$
\text { Pada kegiatan pelatihan yang telah }
$$
dilaksanakan menunjukkan antusiasme yang sangat tinggi dari peserta yang merupakan pelaku UMKM. Antusiasme tersebut ditunjukkan dengan banyaknya pertanyaan yang diajukan seputar pembukuan maupun pengelolaan dan perencanaan keuangan. Narasumber berusaha untuk menjawab pertanyaanpertanyaan tersebut dan memberikan penjelasan yang mendalam mengenai tema yang ditanyakan.

Pertanyaan yang paling banyak diajukan adalah bagaimana cara membuat laporan keuangan sederhana dengan benar dan keuntungan apa yang didapatkan jika sudah dapat membuat pembukuan sederhana. Kebanyakan pelaku UMKM di Kecamatan matesih masih belum paham laporan keuangan apa saja yang harus dibuat. Tim pengabdian juga berharap, materi yang disampaikan dapat langsung dipraktikkan dalam kondisi nyata oleh pelaku UMKM. Menurut pengamatan tim pengabdian pada masyarakat bahwa selama pelaksanaan kegiatan pelatihan tersebut nampak bahwa masyarakat pelaku UMKM di Kecamatan Matesih Kabupaten Karanganyar masih awam dengan pembukuan. Padahal pembukuan ini penting bagi keberlanjutan usaha maupun akses permodalan.

Menurut pengamatan tim pengabdian kepada masyarakat bahwa selama pelaksanaan kegiatan pelatihan tersebut, pembuatan laporan keuangan sederhana masih dirasa awam oleh ibu - ibu Pembinaan Kesejahteraan Keluarga (PKK) terutama yang mempunyai usaha kecil dan menengah di Kecamatan Matesih, Kabupaten Karanganyar. Keberhasilan pelaksanaan program pengabdian masyarakat ini dilihat dari dua indikator yaitu : 
a. Respon posittif dari peserta yang hadir dari awal hingga kegiatan berkahir.

b. Mampu memberikan manfaat bagi peserta dan mudah untuk diterapkan oleh ibu - ibu Pembinaan Kesejahteraan Keluarga terutama yang memiliki usaha kecil dan menengah di Kecamatan Matesih Kabupaten Karanganyar.

\section{KESIMPULAN}

Berdasarkan hasil dan pembahasan kegiatan pengabdian kepada masyarakat yang telah diuraikan sebelumnya, dapat disimpulkan bahwa :

a. Pemahaman dan pendampingan peserta tentang pentingnya pembuatan laporan keuangan sederhana sebagai dasar pentingnya pencatatan keuangan bagi pelaku UKM yang ada di Kecamatan Matesih, Kabupaten Karanganyar.

b. Kemampuan peserta pendampingan pembuatan laporan keuangan sederhana dapat meningkat dan dapat berguna bagi pelaku UKM yang berada di lingkungan Kecamatan Matesih, Kabupaten Karanganyar.

\section{DAFTAR PUSTAKA}

Hairunisya, Nanis., Subiyantoro, Hari. (2016). Pelatihan dan Pendampingan Pembuatan Laporan Keuangan Kepada Pengusaha UMKMdi Kecamatan Karangrejo Kabupaten Tulungangung. JAdimas Volume 4, No 2, Desember 2016 : 31-41.

Layyinaturrobaniyah \& Zusnita, Wa Ode. (2017). Pendampingan Pengelolaan KeuanganUsaha Mikro Di Desa Purwodadi Barat Dan Pasirbungkur Kabupaten Subang. Pekbis Jurnal, Vol.9 N0. 2, Juli 2017.

Santoso, Urip., Widyarini, Maria. (2013). Pelatihan
Pencatatan Keuangan UMKM-Fashion di Kota Cimahi (Kasus UMKM Sweet Batik). Lembaga Penelitan dan Pengabdian Kepada Masyarakat Universitas Katolik Parahyangan 2013. 